\section{Life from an RNA World: the ancestor within}

\section{Book review by Niles Lehman \\ Department of Chemistry, Portland State University, Portland, OR, USA}

Life from an RNA World: the ancestor within (by Michael Yarus, Published in hardback by Harvard University Press, 2010, (198 pages). ISBN-10: 067-405-075-4 ISBN-13: 978-067-405$075-4$ ) is a great place to find all of the arguments for the existence of an "RNA World" neatly compiled in a short and fluid book. I read this pithy work in only a few days while commuting back and forth on public transit. Consequently my first reaction regarding the best audience for the book was that it was for non-scientists, or for those with a basic knowledge of biology but not getting paid to be a scientist. For me it was a smooth, easy read, and I imagine that many of my fellow passengers on the bus or the train saw me nodding my head spontaneously on many occasions.

But in the days that followed after I was done reading, I came to realize that its utility is potentially far greater than a passing fancy for the interested layperson. It came in handy when I needed to explain to my colleagues what the RNA World is all about, it was indispensable when I needed to show my students both inside and out of class - a new feature of the indefatigable RNA molecule, and it served as a conversation piece with more than one acquaintance who knew about the emerging interest in RNA as opposed to its well publicized offspring, DNA. But I also found myself referring to the book directly to look up a couple of pieces of RNA-related trivia for my own research. Thus I am of the opinion that Mike Yarus's new book belongs on the desk of lots of people, from RNA chemists on up to the general public.

The RNA World is a proposed time in the history of the Earth when all the features of life: replication, metabolism, homeostasis, etc., were manifest in RNA molecules or something that was chemically very similar. This time frame was about 4 billion years ago, thus representing the earliest stages of the biological evolutionary journey. Yarus employs the subtitle the ancestor within because the evidence for this period at life's dawn is actually scattered throughout modern-day biochemistry and cell biology. If you look in the right places (and these are not hard to find nowadays), you see signs of how life might have looked preLUCA. And what it looks like is that of a bunch of RNA molecules running around engaged in
Darwinian evolution unaware that their descendents would be so much more adept at making a living that RNA could retire to the Bahamas of the cell and simply wire money to the mainland when needed. As Yarus points out in Chapter 11 ("Intimations of an RNA World"), all you need to do is ask yourself - as Harold White did in 1976 - what exactly is ATP, anyways, and where did it come from? I believe it behooves anyone interested in evolutionary biology to become familiar with these arguments, and so again I can recommend this book to quite a wide range of readers.

Life from an RNA World is organized into 20 brief chapters, each roughly ten pages in length that concludes with a succinct reading list for more information. The first few chapters are dedicated to the notion of descent with modification: Darwin's idea that all life is evolutionarily connected with a history that can be represented by a repeatedly coalescing tree that has a single root. From an organismal perspective, the root lies at the last universal common ancestor, but from a molecular perspective it must trace back much further. Yarus adeptly ties molecular phylogenetic concepts into the properties of the RNA molecule, in order to set the stage for appreciating the likelihood of the RNA World. He thus takes the reader backwards in time, rather than forwards from a prebiotic chemistry viewpoint. This is another testament to the appeal this book would have for evolutionary biologists, who, while in all probability would skim over the descriptions of concepts such as parsimony and sequence identities in a huff, would still be impressed by the centrality of RNA in all of this. Of course rRNA is used for deep (and not so deep) phylogenetic reconstruction, but how many people overtly make the connection between rRNA and its role in the Genetic Code and in protein translation, two of the most Earth-specific oddities of nascent life? It's the ancestor within...

The book goes on to touch on the topics of the chemical origins of life and on the fallacy of the creationsists' arguments against evolution. These will both be of great interest to the naïve reader, and one or both will also probably be well received by specialized biologists. Even though I am reasonably well versed in both topics, I still found myself wholly engaged in the three-page demonstration that a random string of letters could spontaneously mutate with the aid of selection - into a target sequence in a series of steps that numbers in the tens, not the ten-to-the-hundreds. While these two topics are somewhat "off-topic", in retrospect I found them to be enjoyable and not everyone would agree with me that they could
Correspondence: Niles Lehman, Department of Chemistry Portland State University PO Box 751 Portland, OR 97207, USA. E-mail: niles@pdx.edu

Received for publication: 16 July 2010. Accepted for publication: 16 July 2010 .

This work is licensed under a Creative Commons Attribution 3.0 License (by-nc 3.0)

(C) Copyright N. Lehman et al., 2010

Licensee PAGEPress, Italy

Trends in Evolutionary Biology 2010; 2:e5

doi:10.4081/eb.2010.e5

have been skipped.

The last half of the book is dedicated first to the features of RNA that make it uniquely suited to be LUCA's grandmother and then to the relics of the RNA World that can be recreated in the laboratory using biochemical techniques. This is the heart of the story, and if a science professional has even less than a trans-continental plane ride to digest this book, I would suggest starting with Chapter 10 . It is in these later chapters that the RNA World story is most concisely laid out, and those keen to have a primer on test tube evolution, microRNAs, and the origin of the Genetic Code, among other things, will find a wonderful resource. There is much to be learned in these pages; I myself had not been introduced to Xist RNA, which controls X chromosome inactivation, until reading them. The common thread is the pivotal role RNA plays in all of life's functions.

Where the book really shines is in the last five chapters in which the author's own storied body of research into the Genetic Code and the ability of RNA to catalyze peptide-bond formation and tRNA aminoacylation permits a "firsthand" recounting of the evolutionary history of early life. These topics are the ones that describe RNA's first steps into early retirement - where RNA invents proteins to take over the reigns of everyday cellular life. Herein we can see in the clearest detail possible to date how the ancestor within all of us began to bury itself into the barracks of the cell. This is a story that will someday be in the first pages of general biology textbooks, not in the last few.

Overall I found Life from an RNA World to be a captivating book. At times the language is a bit too contrived and cutesy for my tastes (RNA structure is a "tape with a shape"). But it is always the case that what appeals to some won't appeal to all, and I can happily say that there is much appeal in the telling of the RNA World to anyone whose thoughts turn to evolution from time to time. 